Vol 12, Issue 2, 2019

\title{
EVALUATION AND COMPARISON OF CYTOTOXIC EFFECT OF VILAZODONE HYDROCHLORIDE WITH 5-FLUOROURACIL IN HT-29 BOWEL CANCER CELL LINE
}

\author{
LATHA PRIYA A ${ }^{1 *}$, ANUSHA $\mathrm{D}^{1}$, DARLING CHELLATHAI $\mathrm{K}^{1}$, HEMALATHA $\mathrm{A}^{2}$, JEGAN MOHAN $\mathrm{Y}^{3}$ \\ ${ }^{1}$ Department of Pharmacology, Sri Ramachandra Medical College and Research Institute, Porur, Chennai - 600 116, Tamil Nadu, India. \\ ${ }^{2}$ Department of Pharmacology, Karpagam Faculty of Medical Sciences and Research, Coimbatore, Tamil Nadu, India. ${ }^{3}$ Department of \\ General Medicine, Shri Sathya Sai Medical College and Research Institute, Ammapettai, Tamil Nadu, India. \\ Email: drdanusha@gmail.com
}

Received: 13 August 2018, Revised and Accepted: 01 October 2018

\section{ABSTRACT}

Objectives: Vilazodone hydrochloride is a novel selective serotonin reuptake inhibitor (SSRI) used to treat major depressive disorders. There are only sparse data available to know about the SSRI's and its association with colon cancer. This study aims to evaluate and compare the in vitro cytotoxic effect of vilazodone with 5-fluorouracil (5-FU) in HT-29 cell line.

Methods: Cell viability was tested by the 3-(4,5-Dimethylthiazol-2-yl)-2,5-diphenyl tetrazolium bromide (MTT) assay (Mosmann, 1983). Test sample and standard drug in variable concentrations were added to the HT-29 cell lines for incubation over $24 \mathrm{~h}$ under ideal conditions. After washing the test and standard drug sample from the well with saline, MTT was added and incubated for $4 \mathrm{~h}$. Dimethyl sulfoxide of $1 \mathrm{ml}$ was added in all wells after incubation with MTT. The absorbance at $570 \mathrm{~nm}$ was measured with an ultraviolet - spectrophotometer.

Results: The values were tabulated, and the graph was plotted to find the IC-50 value (inhibitory concentration at 50\%) which was struck at $28.5 \mu \mathrm{g} / \mathrm{ml}$ and $12.8 \mu \mathrm{g} / \mathrm{ml}$ for vilazodone hydrochloride and 5-FU, respectively.

Conclusion: The results show that vilazodone hydrochloride has good anticancer property comparable with 5-FU, which would probably play a role as a cytotoxic agent in tumor cells. The proposed mechanism of action could be by activation of caspase- 3 enzyme, thereby increasing apoptosis and indicates its use in coexisting depression and colon carcinoma. Other mechanism includes suppression of oncogene p53, which can be confirmed by future studies.

Keywords: Vilazodone hydrochloride, Colon cancer cell line, 3-(4,5-dimethylthiazol-2-yl)-2,5-diphenyl tetrazolium bromide assay, Selective serotonin reuptake inhibitor.

(c) 2019 The Authors. Published by Innovare Academic Sciences Pvt Ltd. This is an open access article under the CC BY license (http://creativecommons. org/licenses/by/4. 0/) DOI: http://dx.doi.org/10.22159/ajpcr.2019.v12i2.29097

\section{INTRODUCTION}

As per the WHO epidemiology data, "Cancer is a leading cause of death worldwide, accounting for 8.8 million deaths in 2015. The second leading cause of cancer death is colorectal cancer, accounting for 774,000 deaths worldwide" [1]. The treatment of colorectal cancer includes surgery, radiotherapy, and chemotherapy with fluoropyrimidines especially 5-fluorouracil (5-FU) combined with folinic acid and oxaliplatin [2]. Apart from these available treatments, antidepressants are also considerably valued in cancer therapy. In the past two decades, the use of antidepressants principally selective serotonin reuptake inhibitors (SSRI's) in neoplastic diseases has noticeably increased because the majority of cancer patients suffer from depressed mood [3,4]. Distinctly, there is a query whether antidepressants promote or depress tumor growth in experimental animals and patients [5]. Citalopram and fluoxetine were found to suppress cell division in colonic tumor models (in vivo) of mice [6]. Paroxetine and fluoxetine were indeed found to induce apoptosis in lung cancer cells (A549), neuroblastoma cells (SKNAS), and medulloblastoma/rhabdomyosarcoma cells (TE671) [7,8]. On the contrary, it was studied that fluoxetine and paroxetine induce carcinogenesis and promotes the growth of ovarian and mammary tumor [9-11]. Diversely, preclinical studies in tumor implanted rats depict that SSRI's neither have stimulatory nor an inhibitory effect on the growth of tumor [12]. Henceforth, this inconsistent and contradictory data warrants the need for multiple studies to analyze the association of antidepressants and cancer.
Vilazodone hydrochloride: It is a novel SSRI and partial agonist of the serotonin (5-hydroxytryptamine) -1A receptor, used to treat major depressive disorders [13]. Vilazodone was approved in 2011 by the United States - Food and Drug Administration and in August 2015 by Central Drugs Standard Control Organization - India for the treatment of major depressive disorder [14]. Major and most common adverse effects are being acute pancreatitis, sleep paralysis, diarrhea, nausea, and headache [15]. This being a new drug needs to be explored for its association with colon cancer cells.

\section{Aims and objectives}

The aim of the study was to evaluate and compare the effect of vilazodone hydrochloride with 5-FU in the HT-29 colon cancer cell line in vitro using 3-(4,5-dimethylthiazol-2-yl)-2,5-diphenyl tetrazolium bromide (MTT) assay.

\section{Principle of MTT assay}

This colorimetric assay measures the viable cells when the pale yellow MTT dye is acted on by the mitochondrial dehydrogenase enzyme which, in turn, cleaves the tetrazolium ring of MTT resulting in the formation of insoluble and impermeable dark purple colored formazan crystals [16].

\section{METHODS}

\section{Cell Line and Culture}

HT-29 cell lines used in the experiment were obtained from National Centre for Cell Sciences, Pune. The cells were maintained in minimal essential medium (MEM) supplemented with $10 \%$ fetal bovine serum, 
penicillin $(100 \mathrm{U} / \mathrm{ml})$, and streptomycin $(100 \mu \mathrm{g} / \mathrm{ml})$ in a humidified atmosphere of $50 \mu \mathrm{g} / \mathrm{ml} \mathrm{CO}_{2}$ at $37^{\circ} \mathrm{C}$.

\section{PROCEDURE - MTT ASSAY: MOSMANN, 1983}

Cells $\left(1 \times 10^{5} /\right.$ well $)$ were plated and maintained at $37^{\circ} \mathrm{C}$ with $5 \% \mathrm{CO}_{2}$ condition. After attaining confluent stage, samples (Vilazodone and 5-FU) of various concentrations were added and incubated for $24 \mathrm{~h}$. The sample was removed from the well after the incubation period, and the cells were bathed with phosphate-buffered saline $(\mathrm{pH}$ 7.4) or MEM without serum. MTT was added to the cells at a concentration of $100 \mu \mathrm{l} /$ well $(5 \mathrm{mg} / \mathrm{ml})$ and incubated for $4 \mathrm{~h} .1 \mathrm{ml}$ of dimethyl sulfoxide (DMSO) was added after $4 \mathrm{~h}$ of incubation in all the wells. Keeping DMSO as the blank all the test samples were measured with an ultraviolet spectrophotometer at an absorbance of $570 \mathrm{~nm}$. Readings were plotted and the inhibitory concentration at 50\% (IC50) was determined graphically [17]. The percentage (\%) cell viability was calculated using the following formula:
$\%$ Cell viability $=\frac{A_{570} \text { of treated cells }}{A_{570} \text { of control cells }} \times 100$

$\%$ Cytotoxicity $=100-\%$ cell viability

Graphs were plotted to represent percentage of cell cytotoxicity at $\mathrm{Y}$-axis against the concentration of the sample in X-axis.

\section{RESULTS}

The percentage cytotoxicity of vilazodone hydrochloride and 5-FU at various concentrations is as shown in Tables 1 and 2, respectively. It implies that as the dose increases, the percentage viability decreases. Accordingly, the IC50 value of vilazodone hydrochloride was espied at $28.5 \mu \mathrm{g} / \mathrm{ml}$ and depicted in Fig. 1 and the IC50 value was 5-FU ascertained at $12.8 \mu \mathrm{g} / \mathrm{ml}$ and depicted in Fig. 2 .

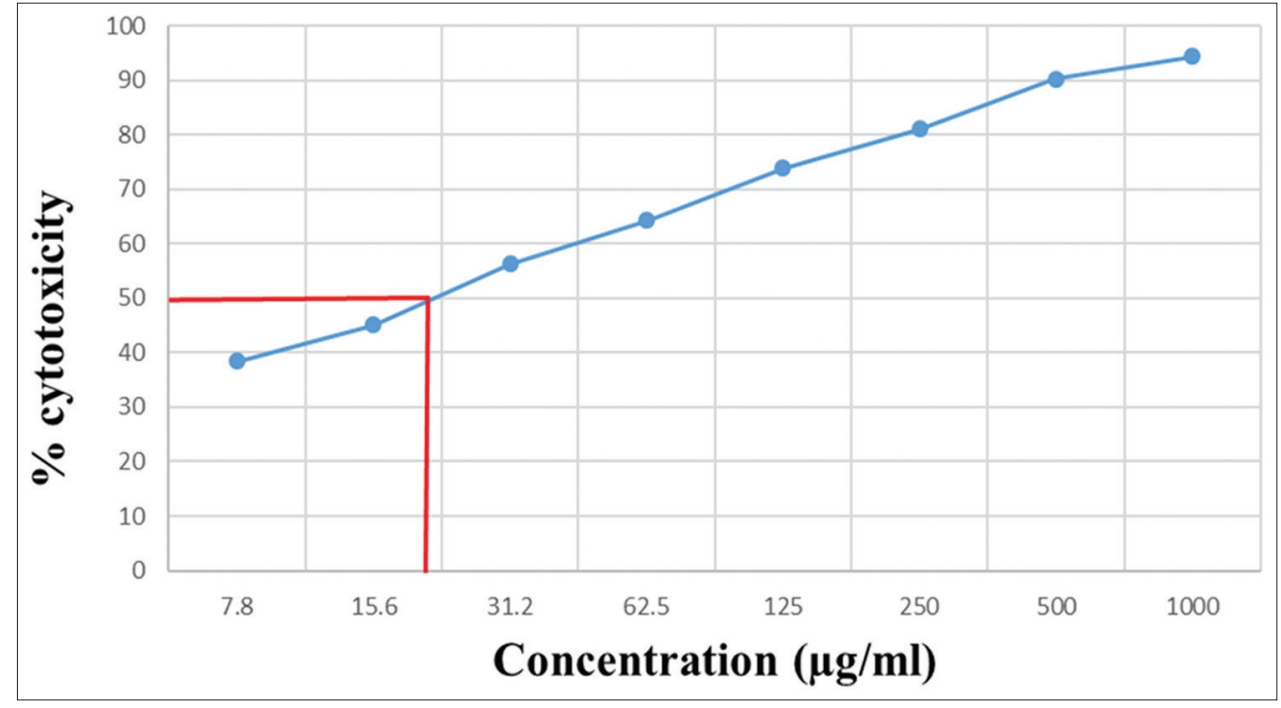

Fig. 1: IC-50 value (Inhibitory concentration at 50\%) of vilazodone hydrochloride

Table 1: Cytotoxic effect of vilazodone on HT-29 cell line

\begin{tabular}{llllll}
\hline S. No. & Concentration $(\boldsymbol{\mu g} / \mathbf{m l})$ & Dilutions & Absorbance (O.D) & Cell viability (\%) & Cell death (\%) \\
\hline 1 & 1000 & Neat & 0.029 & 5.66 & 94.34 \\
2 & 500 & $1: 1$ & 0.050 & 9.76 & 90.24 \\
3 & 250 & $1: 2$ & 0.097 & 18.94 & 81.06 \\
4 & 125 & $1: 4$ & 0.134 & 26.17 & 73.83 \\
5 & 62.5 & $1: 8$ & 0.183 & 35.74 & 56.26 \\
6 & 31.2 & $1: 16$ & 0.224 & 45.75 \\
7 & 15.6 & $1: 32$ & 0.281 & 54.88 & 38.48 \\
8 & 7.8 & $1: 64$ & 0.315 & 61.52 & 0 \\
9 & Cell control & - & 0.512 & 100 & \\
\hline
\end{tabular}

Table 2: Cytotoxic effect of 5-FU on HT-29 cell line

\begin{tabular}{llllll}
\hline S. No. & Concentration $(\boldsymbol{\mu g} / \mathbf{m l})$ & Dilutions & Absorbance (0.D) & Cell viability (\%) & Cell death (\%) \\
\hline 1 & 1000 & Neat & 0.011 & 4.9 & 95.1 \\
2 & 500 & $1: 1$ & 0.042 & 8.20 & 91.80 \\
3 & 250 & $1: 2$ & 0.080 & 15.62 & 84.38 \\
4 & 125 & $1: 4$ & 0.104 & 20.31 & 79.69 \\
5 & 62.5 & $1: 8$ & 0.148 & 28.90 & 65.10 \\
6 & 31.2 & $1: 16$ & 0.176 & 44.37 & 58.60 \\
7 & 15.6 & $1: 32$ & 0.212 & 53.12 & 46.88 \\
8 & 7.8 & - & 0.72 & 100 & 0 \\
9 & Cell control & 0.512 & \\
\hline
\end{tabular}

5-FU: 5-flurouracil, O.D : Optical density 


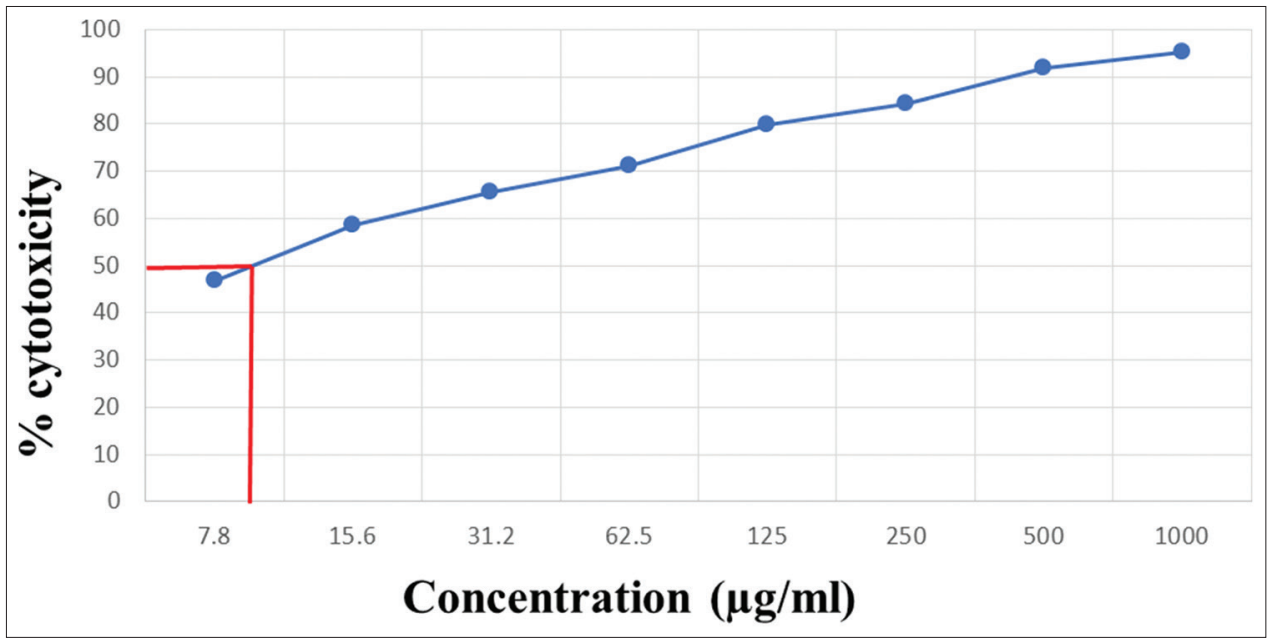

Fig. 2: IC-50 value (Inhibitory concentration at 50\%) of 5-fluorouracil

\section{DISCUSSION}

Apart from modulating neurotransmission, antidepressant drugs have been noted to comport a range of effects, namely, immunomodulation, anti-oxidant, neuroprotection, analgesic, and anti-inflammatory activities, which are due to its influence on glial cell function [18,19]. At present, the scientific community has thrown its light to know about the possible anticancer activity of SSRI's and found that these drugs alter the pivotal cellular mechanism of carcinogenesis [20]. The SSRI's sertraline and paroxetine have been explorated to have anticancer property by arresting the cell division at G0 and G1 phase and by inflating caspase-3 activity in the colon cancer cells [20-22]. Fluoxetine exhibited features of cell death and anti-proliferation of in vitro neuroblastoma cells (SKNAS), Burkitt's lymphoma and breast cancer cells (T47D) [6,23,24]. Further, it was also added that fluoxetine-induced changes in the mitochondrial membrane permeability of human epithelial ovarian cells which resulted in the production of reactive oxygen species and ultimately cell death [24-27]. Correspondingly, our study also infers that vilazodone hydrochloride has got the good cytotoxic effect which is comparable and nearly equipotent with 5-FU in colon cancer cell lines which could be by activation of the Caspase-3 enzyme.

\section{CONCLUSION}

Our study advocates that the novel SSRI, vilazodone hydrochloride has potential cytotoxic effect against the colon cancer cells. As therapy with SSRI is usually indicated in cancer patients, the benefit of using vilazodone hydrochloride in colon cancer patients coupled with depression appears to be attractive.

\section{ACKNOWLEDGMENT}

The authors would like to acknowledge Dr. C. Vasanthi, Professor of Pharmacology for guiding and motivating to carry out the research work.

\section{AUTHORS CONTRIBUTION}

The author would like to thank Dr. D. Anusha and Dr. Darling Chellathai David for supporting to publish this research work. The author extends her gratitude to Dr. A. Hemalatha and Dr. Y. Jegan Mohan for helping in procuring the cell lines, drugs, and chemicals.

\section{CONFLICTS OF INTEREST}

No conflicts of interest.

\section{REFERENCES}

1. GBD 2015 Mortality and Causes of Death Collaborators. Global, regional, and national life expectancy, all-cause mortality, and cause- specific mortality for 249 causes of death, 1980-2015: A systematic analysis for the global burden of disease study 2015. Lancet 2016;388:1459-544.

2. Hamedjwied TA, Nadan A, Mohammed MA. Evaluation of chemo preventive response of pentoxiphylline and sildenafil in colorectal carcinoma experimentally induced in rats: Comparative study with 5-fluorouracil. Int J Pharm Pharm Sci 2015;7 S 1:217-22.

3. Bielecka AM, Obuchowicz E. Antidepressant drugs as a complementary therapeutic strategy in cancer. Exp Biol Med (Maywood) 2013;238:849-58.

4. Kumar MV, Priyanka PS, Prashanth P, Jyothirmai P. Association of patient related risk factors with effectiveness of palliative chemotherapy in cancer patients. Int J Pharm Pharm Sci 2017;9 :.

5. Sternbach $\mathrm{H}$. Are antidepressants carcinogenic? A review of preclinical and clinical studies. J Clin Psychiatry 2003;64:1153-62.

6. Kirkova M, Tzvetanova E, Vircheva S, Zamfirova R, Grygier B, Kubera M, et al. Antioxidant activity of fluoxetine: Studies in mice melanoma model. Cell Biochem Funct 2010;28:497-502.

7. Serafeim A, Holder MJ, Grafton G, Chamba A, Drayson MT, Luong QT, et al. Selective serotonin reuptake inhibitors directly signal for apoptosis in biopsy-like burkitt lymphoma cells. Blood 2003;101:3212-9.

8. Levkovitz Y, Gil-Ad I, Zeldich E, Dayag M, Weizman A. Differential induction of apoptosis by antidepressants in glioma and neuroblastoma cell lines. J Mol Biol 2005;27:29-42.

9. Cosgrove L, Shi L, Creasey DE, Anaya-McKivergan M, Myers JA, Huybrechts KF, et al. Antidepressants and breast and ovarian cancer risk: A review of the literature and researchers' financial associations with industry. PLoS One 2011;6:e18210.

10. Cotterchio M, Kreiger N, Darlington G, Steingart A. Antidepressant medication use and breast cancer risk. Am J Epidemiol 2000;151:951-7.

11. Sharpe CR, Collet JP, Belzile E, Hanley JA, Boivin JF. The effects of tricyclic antidepressants on breast cancer risk. Br J Cancer 2002;86:92-7.

12. Freire-Garabal $M$, Núñez MJ, Pereiro $D$, Riveiro $P$, Losada $C$, Fernández-Rial J, et al. Effects of fluoxetine on the development of lung metastases induced by operative stress in rats. Life Sci 1998;63:PL31-8.

13. Wang SM, Han C, Lee SJ, Patkar AA, Masand PS, Pae CU, et al. A review of current evidence for vilazodone in major depressive disorder. Int J Psychiatry Clin Pract 2013;17:160-9.

14. Laughren TP, Gobburu J, Temple RJ, Unger EF, Bhattaram A, Dinh PV, et al. Vilazodone: Clinical basis for the US food and drug administration's approval of a new antidepressant. J Clin Psychiatry 2011;72:1166-73.

15. Cruz MP. Vilazodone $\mathrm{HCl}$ (viibryd): A serotonin partial agonist and reuptake inhibitor for the treatment of major depressive disorder. J Clin Pharm Ther 2012;37:28.

16. van Meerloo J, Kaspers GJ, Cloos J. Cell sensitivity assays: The MTT assay. Methods Mol Biol 2011;731:237-45.

17. Mosmann T. Rapid colorimetric assay for cellular growth and survival: Application to proliferation and cytotoxicity assays. J Immunol Methods 1983;65:55-63.

18. Xu W, Tamim H, Shapiro S, Stang MR, Collet JP. Use of antidepressants and risk of colorectal cancer: A nested case-control study. Lancet Oncol 2006;7:301-8.

19. Reddy KK, Lefkove B, Chen LB, Govindarajan B, Carracedo A, 
Velasco G, et al. The antidepressant sertraline down regulates akt and has activity against melanoma cells. Pigment Cell Melanoma Res 2008;21:451-6.

20. Torricelli C, Salvadori S, Valacchi G, Souček K, Slabáková E, Muscettola M, et al. Alternative pathways of cancer cell death by rottlerin: Apoptosis versus autophagy. Evid Based Complement Alternat Med 2012;2012:980658.

21. Abdel-Razaq W, Kendall DA, Bates TE. The effects of antidepressants on mitochondrial function in a model cell system and isolated mitochondria. Neurochem Res 2011;36:327-38.

22. Krishnan A, Hariharan R, Nair SA, Pillai MR. Fluoxetine mediates G0/G1 arrest by inducing functional inhibition of cyclin dependent kinase subunit (CKS)1. Biochem Pharmacol 2008;75:1924-34.

23. Stepulak A, Rzeski W, Sifringer M, Brocke K, Gratopp A, Kupisz K, et al. Fluoxetine inhibits the extracellular signal regulated kinase pathway and suppresses growth of cancer cells. Cancer Biol Ther
2008;7:1685-93

24. Cloonan SM, Williams DC. The antidepressants maprotiline and fluoxetine induce Type II autophagic cell death in drug-resistant Burkitt's lymphoma. Int J Cancer 2011;128:1712-23.

25. Kubera M, Lin AH, Kenis G, Bosmans E, van Bockstaele D, Maes M. Anti-inflammatory effects of antidepressants through suppression of the interferon- $\gamma /$ interleukin-10 production ratio. J Clin Psychopharmacol 2001;21:199-206.

26. Koh SJ, Kim JM, Kim IK, Kim N, Jung HC, Song IS, et al. Fluoxetine inhibits NF- $\mathrm{KB}$ signaling in intestinal epithelial cells and ameliorates experimental colitis and colitis-associated colon cancer in mice. Am J Physiol Gastrointest Liver Physiol 2011;301:G9-19.

27. Lee CS, Kim YJ, Jang ER, Kim W, Myung SC. Fluoxetine induces apoptosis in ovarian carcinoma cell line OVCAR-3 through reactive oxygen species-dependent activation of nuclear factor-kappaB. Basic Clin Pharmacol Toxicol 2010;106:446-53. 